\title{
The Validity and Reliability Construct Skills Assessments Skill in Korfball by Using Exploratory Factor Analysis and Confirmatory Factor Analysis
}

\author{
Budi Aryanto*, Awan Hariono, Cukup Pahalawidi \\ Faculty of Sport Science, Yogyakarta State University, Yogyakarta, 55281, Indonesia
}

Received September 22, 2020; Revised February 18, 2021; Accepted February 25, 2021

\section{Cite This Paper in the following Citation Styles}

(a): [1] Budi Aryanto, Awan Hariono, Cukup Pahalawidi, "The Validity and Reliability Construct Skills Assessments Skill in Korfball by Using Exploratory Factor Analysis and Confirmatory Factor Analysis," International Journal of Human Movement and Sports Sciences, Vol. 9, No. 2, pp. 231-235, 2021. DOI: 10.13189/saj.2021.090210.

(b): Budi Aryanto, Awan Hariono, Cukup Pahalawidi (2021). The Validity and Reliability Construct Skills Assessments Skill in Korfball by Using Exploratory Factor Analysis and Confirmatory Factor Analysis. International Journal of Human Movement and Sports Sciences, 9(2), 231-235. DOI: 10.13189/saj.2021.090210.

Copyright $\odot 2021$ by authors, all rights reserved. Authors agree that this article remains permanently open access under the terms of the Creative Commons Attribution License 4.0 International License

\begin{abstract}
This research aims to know the quality of instrument proved through the construct validity and construct reliability of korfball-playing skill assessment. This research and development applied the modified development model of Strand \& Wilson. The performance control sheets were used as the main instrument to observe the korfball-playing skills. The data were analyzed using the Exploratory Factor Analysis (EFA) technique, which is prolonged by the Confirmatory Factor Analysis (CFA) technique to make a good instrument for performing korfball-playing skills observation. The EFA analysis uses software support of SPSS 23.0 and CFA analysis uses software LISREL 8.8. This research is obtained that the estimation of construct of reliability is reliable, where the result of estimation of reliability use confirmatory factor analysis in the indicator of skill execution as well as decision making which are about 0.80 to 0.88 . This research is also obtained of construct of validity is valid, where the result of estimation of validity use confirmatory factor analysis in the indicator of skill execution which are about 0.87 to 0,95 . Estimation of validity in the indicator of decision making is about 0.73 to 0.79 . The result of this research shows that the instrument which used to measure korfball-playing skill is considered valid, reliable, and meets the criteria of a good instrument which shows that the developed assessment model is fit to the actual data.
\end{abstract}

Keywords Assessment, Korfball, Playing Skills, EFA, CFA

\section{Introduction}

Korfball is a game that is relatively new to Indonesia. The game of korfball requires a field with an area of $40 \mathrm{M}$ x $20 \mathrm{M}$. This game uses a ball and a basket with a height of 3.50 meters as the target. One team consists of 6 male players and 6 female players. Each team must split the players into 2 male players and 2 female players to play on the defensive field, and 2 male players and 2 female players in the attacking field. The remaining players, 2 male and 2 female players are the substitutes[1]. The basic skill of korfball player consists of shooting, passing, and rebounding.

The goal of this game is to insert the ball to the opponent's basket and protect our basket from the opponent. This game is a non-contact game. Hence, the players are not allowed to touch each other during the game. In the other words, the game of basket-ball is not a contest of strength, but it is a contest of agility, skill and speed.

Korfball is considered as an invasion game[2]. In order to measure the players' ability or performance, the 
researchers developed the instrument from Game Performance Assessment Instrument (GPAI). GPAI is a multi-dimensional system, designed to measure the ability to play in a particular sport [3]. In the invasion game, the measurements of the players' performance are scored in two components of the seven components that are offered, namely, skill execution and decision making. In this research GPAi developed for assesing the ability of the player in playing korfball after doing practice of korfball. More specific for coaching in korfball sport, GPAI is also developed but only taking the component of skill execcution and decision making.

Skill execution is player's ability to show the performance which is efficient from one skill chosen. In korfball game, there are only three basic skills in playing, such as shooting, passing, and rebounding. Skill execution for on-the-ball in playing korfball is an efficient performance in doing the skill in shooting, passing, and rebounding.

Decision making is player's ability in making choice of the right skill appropriate with the situation when the player mastering the ball. Assessing the decision making is also done by two ways: decision making which is appropriate or right getting value 1 and decision making which is not appropriate or incorrect getting value 0 .

\section{Materials and Methods}

This research is a development research. The expectation final product in this research is good quality instruments for assessing the skills of playing korfball[4]. The data used in this research was the match of the 2019 Senior Korfball National Championship in Yogyakarta. The samples of the data were 100 players, which were 50 male players and 50 female players. In this research, the researchers used survey as the method. It used the observation sheets of skill execution and decision making from three main techniques in korfball, which are shooting, passing and rebound.

The data analysis used exploratory factor analysis and confirmatory factor analysis. Exploratory factor analysis was used to prove the grouping of instrument items into the factors that the researcher wanted or whether it was fit with the theory or not. Exploratory factor analysis also used to determine whether the data collected can be tested by further factor analysis tests. If the KMO and Bartlett's test and anti-image correlation analysis meet the requirements, KMO and Bartlett's test was used to determine whether the sample used was sufficient for factor analysis. Meanwhile, the anti-image correlation values were used to determine whether all instrument items can be used in further research. If the analysis results show that the KMO value $>0.05$, the sample that used is sufficient for factor analysis, and the anti-image correlation values $>0.40$, it means that the items can be used for the further research.

Construct validity provides evidence that the measurement results could be interpreted based on the definition. In the other words, the instrument revealed the capabilities of being measured. The validity of the instrument based on empirical data was analyzed using confirmatory factor analysis[5]. The construct validity was proven by using the loading factor data obtained from the CFA. An observation variable was valid if the measurement of latent variable is greater than $0.3[6]$. In this research, the construct validity was measured by using first order CFA in LISREL 8.8 as a support software.

The first order CFA equation is formulated:

$$
\chi \mathrm{p}=\lambda \mathrm{p} \xi+\delta \mathrm{p}
$$

Where $\chi 1, \chi 2, \ldots \chi p$ is an indicator of the common factors $\lambda 1, \lambda 2 \ldots \lambda \mathrm{p}$ is the loading factor $\delta 1, \delta 2, \ldots \delta \mathrm{p}$ is the unique factor for each error equation.

The reliability analysis technique that used in this research was a multidimensional reliability by using Construct Reliability (CR). It was because the instrument which was developed, contained several aspects. Stated that the presence of multidimensional loads on the test kits that analyzed with the unidimensional model would lead to incorrect estimation of ability and provides misleading information[7]. The Construct Reliability (CR) formula test according to [8]:

$$
\mathrm{CR}=\frac{\left(\sum_{i=1}^{n} \lambda_{i}\right)^{2}}{\left(\sum_{i=1}^{n} \lambda_{i}\right)^{2}+\left(\sum_{i=1}^{n} \varepsilon\right)}
$$

Notes:

$\mathrm{CR}=$ Construct Reliability

$\lambda \mathrm{i}=$ standard loading factor in first indicator

$\varepsilon=$ standard error measurement

This measure of reliability can be accepted if Construct Reliability (CR) has a bigger value than 0.70 .

\section{Results and Discussion}

\subsection{Exploratory Factor Analysis}

The calculation of data analysis exploratory factor analysis, assisted by SPSS 17 is as follows Table 1 .

The results of the SPSS output display Table 1 show the $\mathrm{KMO}$ value of $0.713>0.05$. Hence the further factor analysis tests can be carried out. The Bartlett test value with Chi-square is 185.677 and it is significant at 0.000 . The table 2 shows that all anti-image correlation values show that all items are $>0.40$. Means, the items can be used for further factor analysis.

Bina Darma University Jl. Jenderal Ahmad Yani No.3, 9/10 Ulu, Seberang Ulu I District, Palembang City, South Sumatra 30111. The descriptions of the pretest and posttest data obtained by researchers in this study can be 
seen in table 2.

Table 1. KMO and Bartlett's test

\begin{tabular}{|c|c|c|}
\hline \multicolumn{3}{|c|}{ KMO and Bartlett's Test } \\
\hline \multicolumn{2}{|c|}{ Kaiser-Meyer-Olkin Measure of Sampling Adequacy. } & .702 \\
\hline \multirow{3}{*}{ Bartlett's Test of Sphericity } & Approx. Chi-Square & 221.139 \\
\cline { 2 - 3 } & df & 15 \\
\cline { 2 - 3 } & Sig. & .000 \\
\hline
\end{tabular}

Table 2. The correlation of anti-image matrice

\begin{tabular}{|c|c|c|c|c|c|c|c|}
\hline \multicolumn{8}{|c|}{ Anti-image Matrices } \\
\hline & & $\mathrm{K} 1$ & $\mathrm{~K} 2$ & $\mathrm{~K} 3$ & K4 & K5 & K6 \\
\hline \multirow{6}{*}{$\begin{array}{l}\text { Anti-image } \\
\text { Covariance }\end{array}$} & B01 & .471 & -.242 & -.121 & .071 & -.049 & .012 \\
\hline & B02 & -.242 & .425 & -.176 & -.019 & .070 & -.086 \\
\hline & B03 & -.121 & -.176 & .534 & -.083 & -.097 & .086 \\
\hline & B04 & .071 & -.019 & -.083 & .565 & -.204 & -.180 \\
\hline & B04 & -.049 & .070 & -.097 & -.204 & .529 & -.215 \\
\hline & B05 & .012 & -.086 & .086 & -.180 & -.215 & .578 \\
\hline \multirow{6}{*}{$\begin{array}{l}\text { Anti-image } \\
\text { Correlation }\end{array}$} & B01 & $.690^{\mathrm{a}}$ & -.540 & -.242 & .137 & -.097 & .023 \\
\hline & B02 & -.540 & $.662^{\mathrm{a}}$ & -.370 & -.038 & .148 & -.173 \\
\hline & B03 & -.242 & -.370 & $.758^{\mathrm{a}}$ & -.150 & -.182 & .155 \\
\hline & B04 & .137 & -.038 & -.150 & $.724^{\mathrm{a}}$ & -.373 & -.316 \\
\hline & B05 & -.097 & .148 & -.182 & -.373 & $.694^{\mathrm{a}}$ & -.389 \\
\hline & B05 & .023 & -.173 & .155 & -.316 & -.389 & $.696^{\mathrm{a}}$ \\
\hline
\end{tabular}

The next test is data rotation with varimax rotation. The test results are as shown in Table 3.

Table 3. Matrix of rotated components

\begin{tabular}{|c|c|c|}
\hline \multicolumn{3}{|c|}{ Rotated Component Matrix $^{\mathrm{a}}$} \\
\hline & \multicolumn{2}{|c|}{ Component } \\
\hline & 1 & 2 \\
\hline B01 & .883 & .009 \\
\hline B02 & .889 & .088 \\
\hline B03 & .809 & .201 \\
\hline B04 & .075 & .845 \\
\hline B05 & .132 & .846 \\
\hline B06 & .074 & .827 \\
\hline
\end{tabular}

The results of the items rotation indicated the two components or factors which are named skill execution and decision making. The six items are named as follows, B01 is called shooting skill execution, B02 is called passing skill execution, B03 is called rebound skill execution, B04 is called shooting decision making, B05 is called passing decision making, and B06 is called rebound decision making. Furthermore, it is analyzed by using confirmatory factor analysis to find the construct validity and the construct reliability.

\subsection{Confirmatory Factor Analysis}

CFA First Order Test for Skill Execution and Decision Making Instruments for assessing skills in playing korfball.

The instrument of skill execution and decision making in the assessment of skills in playing korfball which has been determined by the value of empirical validity through EFA, then testing the validity of the test construct through Confirmation Factor Analysis (CFA). CFA was carried out to test the dimensionality of the instruments in this research. The CFA analysis was calculated using LISREL 8.8 software.

The calculation result of korfball skills measurement model, which used the first order CFA show that the $\mathrm{p}$-value $=0.16220(>0.05)$, RMSEA $=0.042(<0.08)$ and chi-square $=11.76>0.05$. Means the model is fit with the data. The results of korfball skills measurement model are presented in Table 4.

Table 4. Test Results of Korfball skill Execution and Decision Instruments Suitability

\begin{tabular}{|c|c|c|c|}
\hline Values & Limit & Index Suitability & Description \\
\hline chi-square & $\geq 0,05$ & $\begin{array}{c}\chi^{2}=11,76 ; \mathrm{df}=8 ; \\
p \text {-value }=0,16220\end{array}$ & Model fit \\
\hline RMSEA & $\leq 0,08$ & 0,042 & Model fit \\
\hline NFI & $\geq 0,90$ & 0,98 & Model fit \\
\hline
\end{tabular}

The information about the index suitability of each item, was drawn from the CFA first order path diagram that presented in Figure 1.

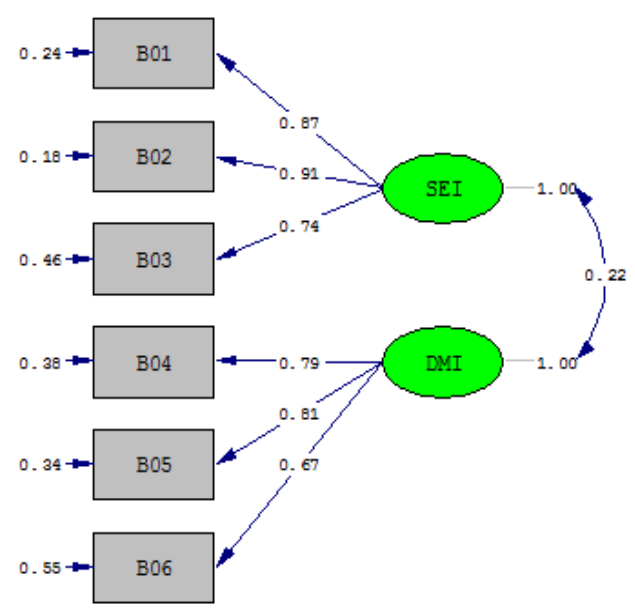

Chi-3quare $=11.76, d f=8, P-v a l u e=0.16230$, RMSEA $=0.043$

Figure 1. Path Diagram of Standard Solution First Order CFA Skills Assessment in Korfball 
The complete information on the calculation of the first order CFA on the korfball skill instrument is presented in Table 5 .

Table 5. Information Fit in first model Korfball skill instrument

\begin{tabular}{|c|c|c|c|c|c|}
\hline No & Indicators & $\begin{array}{c}\text { Loading } \\
\text { Factor }\end{array}$ & $t$-value & $\mathrm{R}^{2}$ & Description \\
\hline 1 & $\begin{array}{c}\text { Shooting } \\
\text { skill } \\
\text { execution }\end{array}$ & 0,87 & 16,29 & 0,76 & Fit \\
\hline 2 & $\begin{array}{c}\text { Passing } \\
\text { skill } \\
\text { execution }\end{array}$ & 0,91 & 17,22 & 0,83 & Fit \\
\hline 3 & $\begin{array}{c}\text { Rebound } \\
\text { skill } \\
\text { execution }\end{array}$ & 0,74 & 12,99 & 0,55 & Fit \\
\hline 5 & $\begin{array}{c}\text { Shooting } \\
\text { decision } \\
\text { making }\end{array}$ & 0,79 & 12,90 & 0,62 & Fit \\
\hline 6 & $\begin{array}{c}\text { Passing } \\
\text { decision } \\
\text { making }\end{array}$ & 0,81 & 13,31 & 0,66 & Fit \\
\hline $\begin{array}{c}\text { Rebound } \\
\text { decision } \\
\text { making }\end{array}$ & 0,67 & 10,88 & 0,49 & Fit \\
\hline
\end{tabular}

Table 5 shows that the fit model measures korfball skills. The component that made the biggest contribution to playing korfball was the second component, namely passing skill execution, which was 0.83 , while the component that made the smallest contribution to playing korfball was the 6th indicator, namely rebound decision making, which was 0.49 .

The complete results of testing the assessment of skills in playing korfball are the value of construct validity $(\mathrm{CV})$ and construct reliability (CR). Item 1 has a CV of 0.91 , item 2 has a CV of 0.95 , and item 3 has a CV of 0.87 . For the skill execution CR instrument is 0.88 . Item 4 has a $\mathrm{CV}$ of 0.73 , item 5 has a $\mathrm{CV}$ of 0.79 , and item 6 has a $\mathrm{CV}$ of 0.75 . The decision making instrument has a CR of 0.80 .

\section{Discussion}

Construct assessment of playing korfball skill consist of assessment toward skill execution and decision making. In skill execution and decision making, there are three basic components of playing korfball assessed such as shooting, passing, and rebounding. This case is proven by EFA and CFA first order tested. The analysis result with EFA shows that grouping the data into two big groups such as skill execution and decision making. The analysis result with EFA also show that the value of KMO is about 0.702 is bigger than 0.50 . The bartlett's test with Chi-square is about 221.139 and the significance in 0.000 , the test of factor analysis can be continued.

The calculation result assessment of the skill by using first order CFA shows that the construct validity of skill execution variable is shooting component which is 0.91 , passing component which 0.95 , and rebounding component which 0.87 . For the skill execution construct reliability is 0.88 . The construct validity of decision-making variable is shooting component which 0.73 , passing component which 0.79 , and rebounding component which 0.75 . For the decision making construct reliability is 0.80 . The results of this study are strengthened by some of the results of previous studies that show the results of reliability validity, as well as an evaluation model for a model research like the one researcher did. Based on the analysis of structural equation model, decision making influence the skill of playing basketball, the number of contributions of decision making toward the skill of playing basketball is about 26 percent, while the contribution which is about 74 percent is influenced by another variable[9]. Athletes with the type IV cardiac rhythm regulation had a more significant contribution of the low-frequency component (LFRn, n.u.) in the regulation of spontaneous respiration than athletes with type I and II cardiac rhythm regulation. In the type II regulation of cardiac rhythm there is a significant decrease in expiratory duration (s), which is also manifested by a significant increase in the ratio of inspiratory and expiratory phases, which may characterize expiratory insufficiency for this type[10]. In conclusion, PAQ-A questionnaire has a high degree of reliability and convergent validity and is acceptable in measuring Malaysian youths' fitness level but is low in measuring criterion validity level[11]. The outcomes of this review highlight the need for evidence-based intervention programmes with the potential of self-monitoring to be incorporated into the national education system[12]. The main findings of this study are in line with those recently reported in the ACSM's European survey even though similar research design and data analysis are limited internationally[13]. The right instrument to determine the validity and reliability is needed so that the results of data retrieval are valid[14]. Evaluation was conducted to determine the validity of the research construct reliability[15]

\section{Conclusion}

Based on the results of the research and hypothetical tests that have been obtained, this study provides the following conclusions:

(a) a. There is a significant influence of skipping exercises on limb muscle explosive results in the participant Futsal Club Bina Darma University.

(b) b. There is a significant influence of bench up-and-down exercises on limb muscle explosive results in the participant Futsal Club Bina Darma University.

(c) c. There is a significant difference in skipping exercises and ups and downs of the bench against the results of limb muscle explosive in the 
participant Futsal Club Bina Darma University. The percentage of the effect of skipping exercise on the explosiveness of the limbs is $26 \%$ and the exercise up and down the bench is $63 \%$ so the difference between the two is $37 \%$.

\section{Acknowledgements}

No external financial support was received for this study. The authors would like to thank all the volunteers who participated in this study for their participation in assisting with data collection.

\section{REFERENCES}

[1] IKF. (2020). The Rules of Korfball. Nederland: Zeist.

[2] Mitchell, S.A., Oslin, J.L., \& Griffin, L.L. (2006). Teaching sport concepts and skills: A tactical games approach (2nd ed.). Champaign, IL: Human Kinetics.

[3] Gréhaigne, J.F., Godbout, P., \& Bouthier, D. (1997). Performance assessment in team sports. Journal of Teaching in Physical Education, 16, 500-516.

[4] Morrow, J.R. Jr; Jackson, A.W; Disch, J.G; \& Mood, D.P. (2005). Measurement and evaluation in human performance 3rd edition. USA: Human Kinetics.

[5] Mardapi D. (2008). Teknik Penyusunan Instrumen Tes dan Nontes. Yogyakarta: Mita Cendekia.

[6] Mardapi, D. (2012). Pengukuran Penilaian \& Evaluasi Pendidikan. Yogyakarta: Nuha Medika

[7] Kartowagiran B. (2008). Validasi dimensionalitas perangkat tes ujian akhir nasional SMP mata pelajaran Matematika 2003-2006. Jurnal Penelitian dan Evaluasi, Nomor 2 Tahun
12, 177-195.

[8] Hair, Joseph F. Jr. et al. (2010), Multivariate Data Analysis 7 th Edition. Pearson Education Limited. Harlow. England

[9] B. Aryanto, P. Sukoco, and R. Lumintuarso, "The validity of construct analysis on assessment instrument of basketball skill for senior high school in Yogyakarta City," Int. J. Hum. Mov. Sport. Sci., vol. 8, no. 5, pp. 193-198, 2020, doi: 10.13189/saj.2020.080506.

[10] A. Romanchuk and O. Guzii, "Variability and pattern of spontaneous respiration in different types of cardiac rhythm regulation of highly trained athletes," Int. J. Hum. Mov. Sport. Sci., vol. 8, no. 6, pp. 483-493, 2020, doi: 10.13189/saj.2020.080622.

[11] D. Koh, N. H. Zainudin, and M. K. Zawi, "Validity and reliability of the modified physical activity questionnaire for adolescents (Paq-a) among Malaysian youth," Int. J. Hum. Mov. Sport. Sci., vol. 8, no. 6, pp. 355-360, 2020, doi: 10.13189/saj.2020.080606.

[12] T. F. T. Kamalden, S. A. Wickramarachchi, S. K. Geok, and Q. Gasibat, "A systematic review of self-monitoring interventions in promoting physical activity among adolescents in south asian countries," Int. J. Hum. Mov. Sport. Sci., vol. 8, no. 6, pp. 321-328, 2020, doi: 10.13189/saj.2020.080603.

[13] A. Batrakoulis, A. Chatzinikolaou, A. Z. Jamurtas, and I. G. Fatouros, "National survey of fitness trends in Greece for 2021," Int. J. Hum. Mov. Sport. Sci., vol. 8, no. 6, pp. 308320, 2020, doi: 10.13189/saj.2020.080602.

[14] Muslimin et al., "Model development of digital based volleyball under service skills instruments," Int. J. Hum. Mov. Sport. Sci., vol. 8, no. 6, pp. 42-46, 2020, doi: 10.13189/saj.2020.080707.

[15] M. Muslimin and A. Hidayat, "Evaluasi Program Pembinaan Tim Sepakbola Sekolah Olahraga Negeri Sriwijaya Sumatera Selatan Tahun 2016," J. Sport AREA, vol. 2, no. 2, p. 53, 2017, doi: 10.25299/sportarea.2017.vol2(2).776. 